\title{
Analysis Efficiency of Sharia Commercial Banks in Indonesia
}

Nadhia Shalehanti"1 Irfan Syauqi Beik, Dedi Budiman Hakim

Economics, IPB University, Bogor, Indonesia

\section{ABSTRACT}

Article Info

Volume 8, Issue 5

Page Number : 86-91

\section{Publication Issue :}

September-October-2021

\section{Article History}

Accepted : 03 Sep 2021

Published: 10 Sep 2021
Indonesia has the potential to become a leader in the development of the Islamic financial market in the world with majority population is Muslim. The Corona Virus Disease 2019 (Covid-19) pandemic has caused decrease in economic growth. However, the distribution of financing by Islamic banks in 2020 increased. With the current progress of the Islamic banking institution in Indonesia, it is necessary to estimation the efficiency level of Islamic banks and the impact of technology on the efficiency of Islamic banks. This research will analyze the efficiency from sharia commercial bank and the effect of internal factors and technology on efficiency. This research will used annual data from sharia commercial bank in 2014 to 2020. To analyze of efficiency will be used Data Envelopment Analysis (DEA) method and used Tobit method to analyze the effect of internal factors and technology on efficiency. In general, the efficiency of sharia commercial bank in Indonesia has a fluctuative tren in 2014-2020. The estimation results of tobit method is return on assets (ROA) has significantly contributing positive effects to efficiency. Meanwhile, technology has significantly contributing negative effect to efficiency.

Keywords : Sharia Commercial Bank, Data Envelopment Analysis (DEA), Efficiency, Technology

\section{INTRODUCTION}

Indonesia as a country with the largest Muslim population has the potential to become a leader in the development of Islamic financial markets in the world, especially developing the Islamic banking sector in Indonesia. The data from Indonesia Information Portal in 2019 showed that the total Muslim population in Indonesia reached 226.9 million or about 87.2 percent of the total population of Indonesia. This is a potential to develop the Islamic finance sector, especially the banking sector. Over time, the development of Islamic Commercial Banks is growing rapidly. This can be seen from the indicators for the development of Islamic Commercial Banks which are shown in Table 1.

Table 1 Indicators of the development of Islamic Commercial Banks 2014-2020
\begin{tabular}{|l|c|c|c|c|c|c|}
\hline Indicators (unit) & 2015 & 2016 & 2017 & 2018 & 2019 & 2020 \\
\hline $\begin{array}{l}\text { Total assets (billion } \\
\text { in rupiah) }\end{array}$ & 213423 & 254184 & 288027 & 316691 & 350364 & 397073 \\
\hline $\begin{array}{l}\text { Islamic commercial } \\
\text { banks }\end{array}$ & 12 & 13 & 13 & 14 & 14 & 14 \\
\hline Branch offices & 1990 & 1869 & 1825 & 1875 & 1919 & 2034 \\
\hline Total of labor & 51413 & 51110 & 51068 & 49516 & 49654 & 50212 \\
\hline $\begin{array}{l}\text { Deposit (billion in } \\
\text { rupiah) }\end{array}$ & 174895 & 279335 & 334888 & 371828 & 416558 & 465977 \\
\hline $\begin{array}{l}\text { Total of financing } \\
\text { (billion in rupiah) }\end{array}$ & 172054 & 178043 & 190354 & 202766 & 225607 & 246957 \\
\hline
\end{tabular}
Sumber: SPS OJK (2020)


From the data showed that total assets, deposit, and financing disbursed by Islamic banks during the period 2015 to 2020 have increased quite well. The year 2020 presented extraordinary challenges for the Indonesian economy. The 2019 Corona Virus Disease (Covid-19) pandemic hit the economy so strongly that economic growth such as consumption, investment and foreign trade declined significantly (Bank Indonesia, 2020). During the Covid-19 pandemic, Islamic Commercial Banks were still able to survive and showed positive improvements where there was an increase in terms of assets, deposit, disbursed financing, branch office, and total of labor.

In working as an intermediary institution, Islamic Commercial Banks are required to work efficiently. Efficiency in the banking world is one of the performance parameters used to see the ability to produce maximum output from available inputs. At the time of obtaining the efficiency measurement, the bank is faced with the condition of how to get the optimal level of output with the existing input level or the minimum level of input with a certain level of output, so that the calculation of the profit level can show a good level of performance, health criteria or achievement from a regulatory perspective. (Hadad et al 2003).

Currently, the use of technology can encourage banks to achieve business growth, as well as being able to accommodate changes in the increasing competitive banking industry. By utilizing technology, it is expected to increase operational efficiency and provide excellent service quality to customers.

In this research, the technologies that will be examined are the use of Automatic Teller Machine (ATM), internet banking, Short Messaging Service (SMS) banking, and mobile banking. The existence of technology-based banking services can improve operational efficiency and service with the Bank. So, in this reasearch will see the efficiency of Islamic
Commercial Banks and the influence of technology and internal factors on efficiency.

\section{METHODS AND MATERIAL}

This research used data from nine Islamic Commercial Banks from annual data for the period 2014 to 2020. The data Islamic Commercial Banks that used are are Bank Muamalat Indonesia, Bank Rakyat Indonesia Syariah (BRI Syariah), Bank Syariah Mandiri (BSM), Bank Mega Syariah, Bank Central Asia Syariah (BCA Syariah), Bank Negara Indonesia Syariah (BNI Syariah), Bank Panin Dubai Syariah, Syariah Pension Savings Bank (BTPN Syariah), and Bukopin Syariah Bank

Furthermore, two research methods will be used, data envelopment analysis (DEA) and the Tobit method. Data envelopment analysis (DEA) showed technical efficiency scores and pure technical efficiency with an output-oriented intermediation approach. Scores of technical efficiency and pure technical efficiency range from $0-1$, the closer to 1 (one), the more efficient the performance of a BUS. Hidayat (2014) divided four categories of efficiency scores, the first is the high category with a score of $0.81-1$. Second, the medium category scores $0.6-0.8$. Third, the low category scores between 0.4-0.5. Last, a not efficient category the score of less than 0.4 .

Table 2. DATA ENVELOPMENT ANALYSIS (DEA)

\begin{tabular}{|l|c|}
\hline \multicolumn{1}{|c|}{ Variable } & Indicator \\
\hline \multirow{2}{*}{ Input } & Deposit \\
\cline { 2 - 2 } & Cost of labor \\
\cline { 2 - 2 } & Total assets \\
\hline \multirow{2}{*}{ Ouput } & Total financing \\
\cline { 2 - 2 } & Operating Income \\
\hline
\end{tabular}

The Tobit method is used to describe the factors that affect efficiency. This second stage of analysis is carried out after first estimating the efficiency score 
in the first stage using the DEA method. The Tobit method assumes that the independent variables have no value limit (non-censored), while the dependent variable has a censored value. The efficiency score ranges from $0-1$, so the Tobit model is the right model to estimate the regression coefficient in the analysis of the determinants of efficiency performance.

There are 2 (two) models estimated in this research. Model 1 will describe the factors that affect the technical efficiency (TE) of the BUS, while model 2 will describe the factors that affect the pure technical efficiency (PTE) of the BUS. The independent variables used in the model are Return on Assets (ROA), Non Performing Financing (NPF), total branch offices, total of ATMs, and technology. The best Tobit regression model produced in this study is generally formulated as follows:

\section{Model 1:}

$\mathrm{TE}_{\mathrm{it}}=\mathrm{b}_{0}+\mathrm{b}_{1} \mathrm{X}_{1 \mathrm{it}}+\mathrm{b}_{2} \mathrm{X}_{2 \mathrm{it}}+\mathrm{b}_{3} \mathrm{X}_{3 \mathrm{it}}+\mathrm{b}_{4} \mathrm{X}_{4 \mathrm{it}}+\mathrm{b}_{5} \mathrm{X}_{5 \mathrm{it}}+\varepsilon_{\mathrm{it}}$ Model 2:

$\mathrm{PTE}_{\mathrm{it}}=\mathrm{b}_{0}+\mathrm{b}_{1} \mathrm{X}_{1 \mathrm{it}}+\mathrm{b}_{2} \mathrm{X}_{2 \mathrm{it}}+\mathrm{b}_{3} \mathrm{X}_{3 \mathrm{it}}+\mathrm{b}_{4} \mathrm{X}_{4 \mathrm{it}}+\mathrm{b}_{5} \mathrm{X}_{5 \mathrm{it}}+\varepsilon_{\mathrm{it}}$

\section{Description:}

$\mathrm{TE}_{\mathrm{it}}=$ score of technical efficiency BUS

$\mathrm{PTE}_{\mathrm{it}}=$ score of pure technical efficiency BUS

bo = intercept

$\mathrm{b}_{1} \quad=$ coefficient

$\mathrm{X}_{\text {lit }} \quad=$ Return on Asset (ROA)

$\mathrm{X}_{2 \mathrm{it}} \quad=$ Non Performing Financing $(\mathrm{NPF})$

$\mathrm{X}_{3 \mathrm{it}}=$ Total of branch offices

$\mathrm{X}_{4 \mathrm{it}} \quad=$ Total of ATMs

$\mathrm{X}_{5 \mathrm{it}}=$ technology

$\varepsilon_{\text {it }} \quad=$ gerror

\section{RESULTS AND DISCUSSION}

\section{A. DEA Method}

As previously explained, technical efficiency (TE) and pure technical efficiency (PTE) range from $0-1$. The closer the score to 1 (one) indicates that the BUS is more efficient in its operational activities. This showed the ability of the BUS to produce a certain number of outputs with a minimum combination of inputs, and the more optimal it is to carry out its function as an intermediary institution. On the other hand, the closer the score to 0 (zero) indicates the less efficient the BUS in its operational activities as an intermediary institution (surplus spending unit) to the DSU (deficit spending unit). Following are the results of data envelopment analysis (DEA) for technical efficiency (TE) and pure technical efficiency (PTE) scores.

\begin{tabular}{|c|c|c|c|c|c|c|c|c|c|c|}
\hline & & $\begin{array}{l}\text { Syariah } \\
\text { Mandiri }\end{array}$ & $\begin{array}{c}\text { BNI } \\
\text { Syariah }\end{array}$ & $\begin{array}{c}\text { BRI } \\
\text { Syariah } \\
\end{array}$ & $\begin{array}{c}\text { BCA } \\
\text { Syariah } \\
\end{array}$ & Muamalast & $\begin{array}{l}\text { Bukgopin } \\
\text { Syariah }\end{array}$ & $\begin{array}{c}\text { Mega } \\
\text { Syariah } \\
\end{array}$ & $\begin{array}{c}\text { Danin } \\
\text { Syariah } \\
\end{array}$ & $\begin{array}{r}\text { BTPN } \\
\text { Syariah }\end{array}$ \\
\hline \multirow{2}{*}{2014} & ET & 0.87128 & 0.966805 & 0.9435 & 0.8909 & 0.862 & 0.9015 & 1 & 1 & 0.95 \\
\hline & PTE & 0.97551 & 0.997274 & 0.9948 & 1 & 1 & 1 & 1 & 1 & 1 \\
\hline \multirow{2}{*}{2015} & ET & 0.95218 & 0.967506 & 0.8443 & 0.85732 & 0.891 & 0.9231 & 0.9724 & 1 & 1 \\
\hline & PTE & 1 & 1 & 0.9287 & 0.89504 & 1 & 0.9488 & 0.9903 & 1 & 1 \\
\hline \multirow{2}{*}{2016} & ET & 0.87987 & 0.907362 & 0.7895 & 0.86779 & 0.899 & 0.8557 & 0.9662 & 0.91 & 0.9927 \\
\hline & PTE & 0.98727 & 0.952902 & 0.8958 & 0.88955 & 1 & 0.857 & 0.9781 & 0.91 & 1 \\
\hline \multirow{2}{*}{2017} & $\mathrm{ET}$ & 0.8614 & 0.848935 & 0.7575 & 0.87903 & 0.837 & 0.7919 & 0.8347 & 0.95 & 1 \\
\hline & PTE & 1 & 0.924089 & 0.9265 & 0.88794 & 0.995 & 0.7937 & 0.8388 & 0.95 & 1 \\
\hline \multirow{2}{*}{2018} & ET & 0.85979 & 0.86121 & 0.7937 & 0.86788 & 0.733 & 0.8419 & 0.8832 & 0.87 & 0.9854 \\
\hline & PTE & 1 & 0.917702 & 0.9976 & 0.86841 & 0.823 & 0.8444 & 0.8859 & 0.88 & 0.9929 \\
\hline \multirow{2}{*}{2019} & ET & 0.60376 & 0.813768 & 0.7946 & 0.82068 & 0.739 & 0.8856 & 0.9491 & 1 & 1 \\
\hline & PTE & 1 & 0.871627 & 0.9419 & 0.82468 & 0.807 & 0.8934 & 0.9542 & 1 & 1 \\
\hline \multirow{2}{*}{2020} & ET & 0.5693 & 0.749765 & 0.866 & 0.72018 & 0.709 & 1 & 0.7954 & 1 & 0.9515 \\
\hline & PTE & 1 & 0.806688 & 1 & 0.72647 & 0.781 & 1 & 0.8377 & 1 & 1 \\
\hline
\end{tabular}

In general, the average efficiency level of nine Islamic Commercial Banks in Indonesia has a fluctuating trend during the study period. In 2014, Bank Mega Syariah and Bank Panin Syariah operated technically efficient. Meanwhile, the banks that experienced pure technical efficiency were all banks except for Bank Syariah Mandiri, BNI Syariah, and BRI Syariah. In 2015, Bank Panin Syariah and BTPN Syariah experienced technical efficiency. Meanwhile, the banks that experienced pure technical efficiency were Bank Syariah Mandiri, BNI Syariah, Bank Muamalat Indonesia, Bank Panin Syariah and BTPN Syariah.

In 2016 there were 2 banks that operated purely technically, Bank Muamalat Indonesia and BTPN Syariah. Meanwhile, in 2017 there were 3 banks operating efficiently, Bank Syariah Mandiri, technically efficient and BTPN Syariah, technically efficient and purely technically efficient. In 2018 
there was only 1 bank that experienced technical efficiency, Bank Syariah Mandiri.

In 2019, there were 3 banks operating efficiently, Bank Syariah Mandiri which operated technically efficiently and Bank Panin Syariah and BTPN Syariah, each of which was technically efficient and technically pure. In 2020 there are 5 banks operating efficiently, Bank Syariah Mandiri, BRI Syariah, Bukopin Syariah, Bank Panin Syariah and BTPN Syariah.

Based on the efficiency score category by Hidayat (2014) Bank Syariah Mandiri has a high score in all research periods except in 2019 and 2020 for technical efficiency scores at low and medium levels. BNI Syariah obtained a high category efficiency score for the entire period except in 2020 for a technical efficiency score at a moderate level. BRI Syariah has an efficiency score in the medium and high categories during 2014-2020. BCA Syariah received a high category efficiency score in 2014-2019, while in 2020 it received a moderate efficiency score for both technical efficiency and pure technical efficiency. Bank Muamalat Indonesia received an efficiency score of medium and high categories during the study period. Likewise, Bank Bukopin Syariah and Bank Mega Syariah got a medium and high efficiency score for 2014-2020. Panin Dubai Syraiah Bank and BTPN Syariah got the best score where in 2014-2020 they got a high efficiency score for 2014-2020.

Although there are still banks that operate efficiently in 2020, in general the efficiency score has decreased. This is because in 2020 there was a Corona Virus Disease 2019 (Covid-19) pandemic which had an impact on the performance of Islamic Commercial Banks. From the table, it showed that there are 2 (two) banks that operate the most efficiently, both technically and purely technically, Bank Panin Syariah and BTPN Syariah. Meanwhile, other banks have fluctuating scores. This result is in line with previous research that BUS has not yet reached the optimal level of efficiency (Amirillah 2014; Parisi 2020; and Firdaus and Hosen 2013).

\section{B. Tobit Method}

In the second stage, the tobit method is used to see the factors that affect technical efficiency and pure technical efficiency. The factors that will be tested are ATM networks, bank branches, Return on Assets (ROA), Non Performing Financing (NPF), and technology owned by banks in the form of e-banking (internet banking, sms banking, and mobile banking). The following is the output using the tobit method.

\begin{tabular}{|c|c|c|}
\hline \multirow{2}{*}{ Variabel } & $\begin{array}{c}\text { Model } 1 \\
\text { TE }\end{array}$ & $\begin{array}{c}\text { Model } 2 \\
\text { PTE }\end{array}$ \\
\hline & \multicolumn{2}{|c|}{ Koefisien (Prob.) } \\
\hline Return on Asset (ROA) & $\begin{array}{l}0.008917 \\
\left(0.0168^{*}\right)\end{array}$ & $\begin{array}{c}0.006780 \\
\left(0.0215^{*}\right)\end{array}$ \\
\hline Non Performing Financing (NPF) & $\begin{array}{c}0.008952 \\
(0.2666)\end{array}$ & $\begin{array}{c}0.001109 \\
(0.8618)\end{array}$ \\
\hline Total of branche office & $\begin{array}{c}-0.000545 \\
(0.2260) \\
\end{array}$ & $\begin{array}{c}0.000364 \\
(0.3060)\end{array}$ \\
\hline Total of ATMs & $\begin{array}{c}-2.61 \mathrm{E}-05 \\
(0.4954)\end{array}$ & $\begin{array}{c}3.29 \mathrm{E}-05 \\
(3.29 \mathrm{E}-05)\end{array}$ \\
\hline Technology & $\begin{array}{l}-0.072704 \\
(0.0122 *)\end{array}$ & $\begin{array}{l}-0.075221 \\
\left(0.0010^{*}\right)\end{array}$ \\
\hline $\mathrm{C}$ & $\begin{array}{l}0.940199 \\
(0.0000)\end{array}$ & $\begin{array}{l}0.961282 \\
(0.0000)\end{array}$ \\
\hline Mean dependent var & 0.877521 & 0.939353 \\
\hline S.D. dependent var & 0.096264 & 0.073051 \\
\hline Jarque-Bera (J-B) & 2.008840 & 5.146507 \\
\hline Prob. & 0.366257 & 0.76287 \\
\hline
\end{tabular}

The dependent variable in the TE model has an average value of 0.877521 and a standard deviation of 0.096264 . These results indicate that the average value is greater than the standard deviation, thus indicating that the results are good. The dependent variable in the PTE model has an average value of 0.939353 and a standard deviation of 0.073051 . These results indicate that the mean value is greater than the standard deviation, thus indicating that the results are good.

From the test results in table 4 it is found that Return on Assets (ROA) has a positive and significant effect on technical efficiency (TE) or pure technical efficiency (PTE). This can be seen from the t-statistics showing the ROA variable has a probability that is smaller than the 5\% significance level () with coefficient values of 0.008917 and 0.006780 . The values of 1 obtained are 0.008917 and 0.006780 with a positive sign indicating that every 1 percent increase 
in ROA can increase the technical efficiency (TE) of the BUS by 0.008917 percent ceteris paribus. Likewise with the results in model 2 , the value of 1 obtained is 0.006780 with a positive sign indicating that every $1 \%$ increase in $\mathrm{ROA}$ is expected to increase the pure technical efficiency (PTE) of the BUS by 0.006780 percent, ceteris paribus.

Furthermore, the Non-Performing Financing (NPF) variable has a probability greater than the 5\% significance level $(\alpha)$ with probability values of 0.2666 and 0.8618 . This shows that the NonPerforming Financing (NPF) variable is not significant to technical efficiency and pure technical efficiency.

Based on the results of the Tobit regression test model 1 , the bank branch variable has a negative but not significant effect. This can be seen from the probability that is greater than the $5 \%$ level of significance $(\alpha)$ with a probability value of 0.2260 . Different results are obtained in model 2 where in this model the bank branch has a positive but not significant effect on efficiency with a probability value greater than the $5 \%$ level of significance $(\alpha)$ which is 0.3060 .

The variable number of ATMs has no significant effect on efficiency, this is obtained from the probability value greater than the $5 \%$ significance level $(\alpha)$ which is 0.4954 and 3.29E-05 for technical efficiency (TE) and pure technical efficiency (PTE). There are differences in coefficients in models 1 and 2 where model 1 has a negative coefficient value while model 2 has a positive value.

Furthermore, from the results of the Tobit regression test, it was found that technologi has a negative and significant effect on efficiency based on a probability value smaller than the $5 \%$ real level $(\alpha)$ which is 0.0122 and 0.0010 for model 1 and model 2. 1, every 1 percent increase in the use of technology can reduce the technical efficiency (TE) of the BUS by 0.072704 percent ceteris paribus. Likewise with the results in model 2 , the value of 1 obtained is 0.075221 with a negative sign indicating that every 1 percent increase in e-banking is thought to reduce the pure technical efficiency (PTE) of BUS by 0.075221 percent, ceteris paribus.

\section{IV.CONCLUSION}

In general, BUS in Indonesia has an efficiency score in the medium and high categories. This is evident from the TE and PTE scores, which generally have not reached a perfect score of 1 (one). From the TE and PTE scores, it is proven that BUS has a fairly good performance efficiency of Islamic commercial banks. However, in 2020, in general, the efficiency of Islamic Commercial Banks decreased due to the Covid-19. The factor that has a significant positive effect on efficiency is return on assets (ROA). The higher the ROA of the BUS, the higher the efficiency of the BUS. Banks that can generate greater profits can be indicated as efficient banks. The factor that has a significant negative effect on efficiency is technology. This indicates that the use of technology in this case e-banking carried out by Islamic Commercial Banks is not good enough because the use of technology will decrease the efficiency of Islamic Commercial Banks.

\section{REFERENCES}

[1]. Alfatihah P, Sundari B, "Pengaruh Transaksi Perbankan Elektronik (Electronic Banking) Terhadap Kinerja Keuangan Entitas Publik Perbankan” Jurnal Ilmiah Ekonomi Bisnis, 2021

[2]. Ascarya, Yumanita D, "Comparing the Efficiency of Islamic Banks in Malaysia and Indonesia," Bank Indonesia: Buletin Ekonomi Moneter dan Perbankan, 2008.

[3]. Ascarya, Yumanita D, “Analisis Efisiensi Perbankan Syariah di Indonesia dengan Data 
Envelopment Analysis," TAZKIA Islamic Finance and Business, 2006.

[4]. Farrell, "The Measurment of Productivity Efficiency" Journal of the Royal Statistical Society, 1957

[5]. Firdaus MF, Hosen MN, "Efisiensi Bank Umum Syariah Menggunakan Pendekatan Two Stage Data Envelopment Analysis," Bank Indonesia:Buletin Ekonomi Moneter dan Perbankan, 2013.

[6]. Hadad MD, Santoso W, Ilyas D, Mardanugraha E, "Analisis Efisiensi Industri Perbankan Indonesia: Penggunaan Metode Non-Parametrik Data Envelopment Analysis (DEA)", Bank Indonesia: Buletin Ekonomi Moneter dan Perbankan, 2003.

[7]. Hadad MD, Santoso W, Ilyas D, Mardanugraha E, "Pendekatan Parametrik untuk Efisiensi Perbankan Indonesia", Bank Indonesia: Buletin Ekonomi Moneter dan Perbankan, 2008.

[8]. Hidayat R, "Efisiensi Perbankan Syariah: dari Teori ke Praktek," Bekasi (ID): Gramata Publishing, 2014.

[9]. Karimah, S, "Kajian Efisiensi Bank Umum Syariah di Indonesia dan Faktor-Faktor yang Memengaruhinya," [thesis]. Bogor: Institut Pertanian Bogor. 2016

[10].Meepadung N, Tang JCS, Khang DB, "IT-based banking services: Evaluating operating and profit efficiency at bank branches," Journal of High Technology Management Research, 2009

[11].Parisi SA, "Kinerja Bank Umum Syariah di Indonesia dengan Pendekatan Efisiensi dan Indeks Maqāshid Syarīah," [thesis]. Bogor (ID) Institut Pertanian Bogor, 2020

[12].Rusydiana AS, Laila N, Sudana, "Efisiensi dan produktivitas perbankan pada sistem moneter ganda di Indonesia” Jurnal Siasat Bisnis, 2016

[13].Sofia GN, “Analisis Faktor Penentu Tingkat Efisiensi Perbankan di Indonesia pada Tahun 2012-2014 dengan Menggunakan Pendekatan Two Stage Data Envelopment Analysis” Jurnal Ilmu Manajemen
[14].Srairi SA, "Cost and profit efficiency of conventional and islamic banks in GCC counties" Springer Science and Business, 2010

\section{Cite this article as :}

Nadhia Shalehanti, Irfan Syauqi Beik, Dedi Budiman Hakim, "Analysis Efficiency of Sharia Commercial Banks in Indonesia ", International Journal of Scientific Research in Science, Engineering and Technology (IJSRSET), Online ISSN : 2394-4099, Print ISSN : 2395-1990, Volume 8 Issue 5, pp. 86-91, September-October 2021. Available at doi : https://doi.org/10.32628/IJSRSET218510 Journal URL : https://ijsrset.com/IJSRSET218510 